\title{
Good Corporate Governance dan Tax Management (Studi Empiris pada Perusahaan Perbankan yang Terdaftar Di BEI Tahun 2013-2015)
}

\author{
Yenni Carolina \\ Fakultas Ekonomi Program Studi Akuntansi-Univ.Kristen Maranatha \\ (Jl. Prof. Drg. Suria Sumantri No. 65, Bandung) \\ yenzcarolina@gmail.com
}

\begin{abstract}
The purpose of this study is to examine the effect of good corporate governance (GCG) using GCG mechanism to tax management. The sample used in this study was chosen based on purposive sampling, 18 banks listed on the Indonesia Stock Exchange in 2013-2015 with 54 observation data was collected as sampels. Data were analyzed using multiple linear regression analysis. Based on data processing, it can be seen that institutional ownership, managerial ownership, and audit committee have a positive effect on tax management, while independent commissioners have no effect on tax management.
\end{abstract}

Keywords: GCG, Independent Commissioner and Audit Committee Tax Management, Institutional Ownership, Managerial Ownership

\section{Pendahuluan}

Panama papers yang terungkap di tahun 2016, menunjukkan perlunya penataan dan perubahan atas tata kelola (governance) yang terkait dengan sistem perpajakan (Khirun Nikmah, 2016). Corporate governance berhubungan dengan tax management karena membayar pajak yang kecil dianggap menghemat pengeluaran untuk kepentingan kesejahteraan pemegang saham (Chen et al, 2008) karenanya direksi dan CEO memegang peranan penting dalam menentukan strategi tax management (Minnick \& Noga, 2010).

Salah satu kewajiban manajemen perusahaan adalah memanfaatkan sumber daya perusahaan secara efisien sehingga dapat meningkatkan kinerja perusahaan dan salah satu cara yang dapat dilakukan adalah dengan melakukan efisiensi di dalam pembayaran pajak (Hendra Putra Irawan dan Aria Farahmita, 2012). Efisiensi dalam membayar pajak adalah proses yang dilakukan untuk mengelola pajak, dan hal ini merupakan bagian dari tax planning atau perencanaan pajak (Lal \& Vashisht, 2008). Perusahaan melakukan tax management atau tax planning untuk meminimalkan kewajiban pajak, yang biasanya dilakukan melalui tax avoidance yang dilakukan secara legal, yaitu penghindaran pajak sesuai peraturan pajak dengan cara mengetahui jenis transaksi yang menguntungkan perusahaan dari sisi penghematan pajak (Firman, 2013).
Good Corporate Governance (GCG) merupakan sistem yang dirancang untuk mengarahkan pengelolaan perusahaan secara profesional berdasarkan prinsip-prinsip transparansi, akuntabilitas, tanggung jawab, independen, kewajaran dan kesetaraan. Penerapan GCG merupakan salah satu syarat bagi perusahaan di Indonesia untuk dapat bersaing dalam skala nasional dan internasional karena perusahaan yang memiliki tata kelola yang baik akan memiliki daya tahan lebih kuat dalam menghadapi berbagai risiko. Disamping itu, GCG juga dapat meningkatkan nilai dan kepercayaan sebuah perusahaan karena Corporate Governance dapat mendorong terbentuknya pola kerja manajemen yang bersih, transparan, dan professional (M. Arief Effendy, 2016).

Berdasarkan data yang dikeluarkan oleh Asian Development Bank (ADB), Indonesia telah menunjukkan tingkat komitmen yang tinggi di dalam meningkatkan tata kelola perusahaan. Peningkatan tersebut tidak terlepas dari peran Otoritas Jasa Keuangan (OJK) yang telah mengeluarkan peraturanperaturan dalam pelaksanaan GCG (ASEAN Corporate Governance Scorecard Country Reports and Assessments, 2014). Institute for Corporate Directorship (IICD) yang mengukur pelaksanaan GCG di kawasan Asia Tenggara mencatat adanya peningkatan skor penilaian GCG dari tahun 2012 hingga 2014, walaupun Indonesia masih berada di urutan dua bawah, di atas Vietnam 
(marketbisnis.com). Penelitian yang dilakukan oleh McGee (2008), juga menunjukkan bahwa Indonesia berada di dua urutan terakhir di dalam skor penilaian GCG yang dilakukan pada 8 negara di Asia.

Paparan di atas diperkuat oleh penelitian yang dilakukan oleh Minnick and Noga (2010) yang menyatakan bahwa tata kelola berpengaruh terhadap tax management. Lebih lanjut dijelaskan dalam penelitiannya bahwa tax management merupakan hal yang kompleks dan tidak memberikan pengaruh secara langsung terhadap perusahaan tetapi tax management memberikan pengaruh jangka panjang sehingga penting untuk memahami pengaruh dari tata kelola atas tax management.

\section{Kerangka Teoritis \& Kerangka Pemikiran dan Hipotesis}

Forum Corporate Governance on Indonesia (FCGI), menjelaskan bahwa "Corporate Governance adalah seperangkat peraturan yang mengatur hubungan antara pemegang saham, pengurus (pengelola) perusahaan, pihak kreditur, pemerintah, karyawan, serta para pemegang kepentingan internal dan eksternal lainnya yang berkaitan dengan hak-hak dan kewajiban mereka" (M. Arief Effendy, 2016). Lebih lanjut, M. Arief Effendy (2016) memaparkan bahwa "perangkat tata kelola (governance) dari suatu organisasi sebagai sistem yang terbuka (open system) terdiri atas struktur tata kelola (governance structure), mekanisme tata kelola (governance mechanism), dan prinsip-prinsip tata kelola (governance principles). Ketiga perangkat ini berjalan sebagai suatu kesatuan dalam bentuk sistem tata kelola (governance system) yang berinteraksi dengan lingkungan internal dan eksternal organisasi dalam mencapai tujuan organisasi yang telah ditetapkan sebelumnya. Efektivitas perangkat tata kelola ini dinilai dari seberapa jauh sistem dimaksud mampu memberikan hasil tata kelola (governance outcomes) yang diharapkan".

Fadhilah (2014) menyatakan bahwa mekanisme dalam corporate governance ada dua yaitu internal dan eksternal. "Mekanisme internal adalah cara untuk mengendalikan perusahaan dengan menggunakan struktur dan proses internal seperti rapat umum pemegang saham, komposisi dewan direksi, proporsi dewan komisaris independen, dan pertemuan dengan board of director. Sedangkan mekanisme eksternal adalah seperti pengendalian oleh perusahaan, struktur kepemilikan, dan pengendalian pasar".

Minnick dan Noga (2010) mendefinisikan tax management sebagai kemampuan perusahaan di dalam melakukan pembayaran pajak dengan jumlah yang lebih sedikit dalam jangka waktu panjang. Menurut Friese (2006), sistem perpajakan dapat mempengaruhi tata kelola perusahaan. Lebih mendalam dijelaskan bahwa antara perpajakan dengan tata kelola juga memiliki hubungan dimana sistem tata kelola dan budaya organisasi akan berpengaruh pada perpajakan perusahaan, terutama di dalam tax planning dan tax compliance. Tata kelola berpengaruh pada tax management, karena dalam hal ini direksi dan CEO memainkan peran yang integral untuk memilih strategi tax management. Pihak manajemen puncak bertanggung jawab untuk memberikan kebijakan terkait dengan alokasi sumber daya, kinerja, dan peningkatan kekayaan pemegang saham. Pada penelitian ini, tax management dapat dilihat dari perbedaan antara laba akuntansi dan laba fiskal atau dikenal dengan istilah book tax gap (Firman, 2013; Bovi, 2005 ; Desai dan Dharmapala, 2009).

Pada penelitian ini juga akan lebih difokuskan pada mekanisme GCG yang diukur melalui kepemilikan manajerial, kepemilikan institusional, proporsi dewan komisaris independen, dan keberadaan komite audit. Menurut Sutojo dan Aldridge (2005) "kepemilikan manajerial adalah situasi dimana manajer memiliki saham perusahaan atau dengan kata lain manajer tersebut sekaligus sebagai pemegang saham perusahaan. Dalam laporan keuangan, keadaan ini ditunjukkan dengan besarnya persentase kepemilikan saham perusahaan oleh manajer". Pada penelitian ini, kepemilikan manajerial diukur dengan menggunakan indikator persentase jumlah saham yang dimiliki oleh manajemen dimiliki pihak manajemen dari seluruh saham perusahaan yang beredar. Dengan demikian hipotesis 1 yang diajukan adalah kepemilikan manajerial berpengaruh positif terhadap tax management.

Kepemilikan institusional adalah kepemilikan saham perusahaan yang dimiliki oleh institusi atau badan "Tingkat kepemilikan institusional yang tinggi akan menimbulkan usaha pengawasan yang lebih besar oleh pihak investor institusional sehingga dapat menghalangi perilaku opportunistic manajer" (Utami dan Rahmawati, 2009). Dalam penelitian ini kepemilikan institusional diukur dengan menggunakan indikator persentase jumlah saham yang dimiliki institusi dari seluruh modal saham yang beredar. Dengan demikian hipotesis 2 yang diajukan adalah kepemilikan institusional berpengaruh positif terhadap tax management.

Keberadaan komisaris Independen pada perusahaan publik sudah menjadi kebutuhan, sehingga keberadaannya diatur dalam UndangUndang Nomor 40 Tahun 2007 tentang Perseroan Terbatas (UUPT). Dalam UUPT, komisaris independen diangkat berdasarkan keputusan RUPS dari pihak yang tidak terafiliasi dengan pemegang saham utama, anggota direksi dan/atau anggota dewan komisaris lainnya. Komisaris independen berperan dalam mewakili kepentingan pemegang saham minoritas yang dimiliki oleh publik, dan keberadaan komisaris independen yang memiliki kompetensi merupakan salah satu pendorong 
implementasi GCG. Proporsi dewan komisaris independen, pada penelitian ini dihitung dengan cara membagi jumlah dewan komisaris independen dengan total anggota dewan komisaris. Dengan demikian hipotesis 3 yang diajukan adalah proporsi dewan komisaris independen berpengaruh positif terhadap tax management.

Komite audit diketuai oleh komisaris independen, melalui komite audit diharapkan dapat meningkatkan akuntabilitas dan efektivitas dewan komisaris, terutama mengenai pengendalian internal, manajemen risiko, pengungkapan laporan keuangan perusahaan serta praktik-praktik GCG secara keseluruhan. Tanggung jawab Komite Audit dalam bidang Corporate Governance adalah untuk memastikan, bahwa perusahaan telah dijalankan sesuai undang-undang dan peraturan yang berlaku, melaksanakan usahanya dengan beretika, melaksanakan pengawasannya secara efektif terhadap benturan kepentingan dan kecurangan yang dilakukan oleh karyawan perusahaan. Komite Audit mempunyai peran yang sangat penting dan strategis dalam hal memelihara kredibilitas proses penyusunan laporan keuangan seperti halnya menjaga terciptanya sistem pengawasan perusahaan yang memadai serta dilaksanakannya GCG (FCGI). Keberadaan komite audit pada penelitian ini dihitung berdasarkan jumlah komite audit yang terdapat dalam perusahaan tersebut. Dengan demikian hipotesis 4 yang diajukan adalah keberadaan komite audit berpengaruh positif terhadap tax management.

\section{Metode Penelitian}

Penelitian ini menggunakan data sekunder yang diperoleh dari laporan keuangan tahunan perusahaan perbankan (annual report) yang terdaftar di Bursa Efek Indonesia (BEI) pada tahun 2013-2015. Jenis penelitian yang dipakai dalam penelitian ini adalah penelitian kuantitatif dengan melakukan uji hipotesis. Populasi dalam penelitian ini adalah perusahaan perbankan yang terdaftar pada BEI pada periode 2013-2015. Kriteria yang digunakan untuk pemilihan sampel adalah perusahaan perbankan yang terdaftar di BEI selama tiga tahun berturut-turut, tidak delisting dan mempublikasikan annual report dari periode 2013-2015, dan mengungkapkan informasi mengenai kepemilikan manajerial, kepemilikan intitusional, proporsi dewan komisaris independen, dan komite audit. Penarikan sampel dalam penelitian ini dipilih berdasarkan purposive sampling, sehingga terkumpul 18 perbankan yang memenuhi kriteria untuk diolah dengan 54 data observasi.

\section{Teknik Analisis Data}

Statistik deskriptif digunakan untuk memberikan gambaran atau deskripsi suatu data yang dilihat dari nilai rata-rata (mean), standar deviasi, varian, maksimum, minimum, sum, range, kurtosis dan skewness (Imam Ghozali, 2013). Statistik deskriptif yang digunakan dalam penelitian ini meliputi nilai minimum, maksimum, rata-rata, dan standar deviasi.

Uji asumsi klasik dilakukan dalam penelitian ini untuk menguji apakah data yang terkumpul memenuhi asumsi klasik yang terdiri dari uji normalitas, uji multikolinearitas, uji heteroskedastisitas dan uji autokorelasi. Pengujian hipotesis dilakukan dengan menggunakan metode regresi linier sederhana. Pengaruh variabel independen terhadap variabel dependen dapat dijelaskan dengan persamaan regresi sebagai berikut:

$$
\begin{array}{ll} 
& \mathrm{Y}=\boldsymbol{\beta}_{\mathbf{0}}+\boldsymbol{\beta}_{\mathbf{1}} \mathbf{X}_{\mathbf{1}}+\boldsymbol{\beta}_{\mathbf{2}} \mathbf{X}_{\mathbf{2}}+\boldsymbol{\beta}_{\mathbf{3}} \mathbf{X}_{\mathbf{3}}+\boldsymbol{\beta}_{\mathbf{4}} \mathbf{X}_{\mathbf{4}}+\varepsilon \\
\text { Dimana: } & \\
\mathrm{X}_{1} & \text { : } \text { Book Tax Gap (variabel Y) } \\
\mathrm{X}_{2} & \text { : Kepemilikan manajerial } \\
\mathrm{X}_{3} & \text { : Kepemilikan institusional } \\
\mathrm{X}_{4} & \text { : Proporsi dewan komisaris independen } \\
\mathrm{Y} & \text { : Keberadaan komite audit } \\
\varepsilon & : \text { Error }
\end{array}
$$

\section{Hasil Penelitian dan Pembahasan}

\section{Statistik Deskriptif}

Tabel 1 di bawah ini menunjukkan statistik deskriptif berdasarkan pengolahan data yang dilakukan.

Tabel 1

Statistik Deskriptif

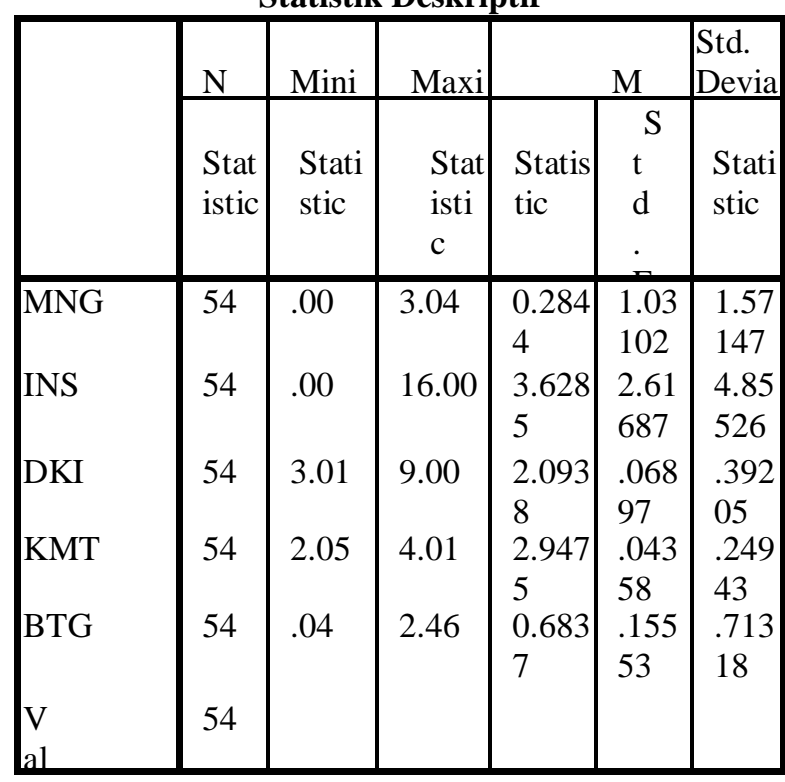

Berdasarkan hasil pengolahan data di atas dapat dilihat bahwa nilai minimum untuk kepemilikan manajerial sebesar 0,00 sedangkan nilai maksimum untuk kepemilikan manajerial sebesar 39,04 dan nilai mean sebesar 0,2844. Hal ini dapat diartikan bahwa rata-rata saham yang dimiliki manajerial pada 
perusahaan perbankan yang menjadi sampel penelitian cukup kecil.

Nilai minimum untuk kepemilikan institusional sebesar 0,00 sedangkan nilai maksimum untuk kepemilikan manajerial sebesar 16.00 dan nilai mean sebesar 3.6285. Hal ini dapat diartikan bahwa rata-rata saham yang dimiliki institusional pada perusahaan perbankan yang menjadi sampel penelitian juga cukup kecil.

Nilai minimum untuk proporsi dewan komisaris independen sebesar 3,01, sedangkan nilai maksimum untuk proporsi dewan komisaris independen sebesar 9,00. Nilai Mean dari proporsi dewan komisaris independen sebesar 2.0938. Hal ini berarti bahwa proporsi dewan komisaris independen pada perusahaan perbankan yang menjadi sampel penelitian masih kurang memenuhi aturan yang dikeluarkan oleh OJK NOMOR 33 /POJK.04/2014 bahwa komisaris independen sekurang-kurangnya $30 \%$ dari seluruh jumlah anggota komisaris.

Nilai minimum untuk komite audit sebesar 2,05 sedangkan nilai maksimum untuk kepemilikan manajerial sebesar 4.01 dan nilai mean sebesar 2,9475. Hal ini berarti bahwa proporsi dewan komisaris independen pada perusahaan perbankan yang menjadi sampel penelitian telah memenuhi aturan yang dikeluarkan oleh OJK NOMOR 55 /POJK.04/2015 bahwa komite audit paling sedikit terdiri dari 3 (tiga) orang anggota yang berasal dari komisaris independen dan pihak dari luar emiten atau perusahaan publik.

Nilai minimum untuk tax management sebesar 0.84 sedangkan nilai maksimum untuk kepemilikan manajerial sebesar 6.46 dan nilai mean sebesar 1.6837 .

\section{Uji Asumsi Klasik}

Tabel 2

Hasil Pengujian Normalitas One-Sample Kolmogorov Smirnoff

\begin{tabular}{|ll|r|}
\hline & & $\begin{array}{c}\text { Unstandardized } \\
\text { Residual }\end{array}$ \\
\hline $\mathrm{N}$ & Mean & 54 \\
Normal Parameters ${ }^{\mathrm{a}, \mathrm{b}}$ & .0000000 \\
& Std. Deviation & 2.41849056 \\
Most Extreme Differences & Absolute & .123 \\
& Positive & .121 \\
Kolmogorov-Smimov Z & Negative & -.061 \\
Asymp. Sig. (2-tailed) & & .673 \\
a. Test distribution is Normal. \\
b. Calculated from data.
\end{tabular}

Berdasarkan hasil pengujian dengan menggunakan One-Sample Kolmogorov-Smirnov Test, data memiliki distribusi normal, karena memiliki nilai sig (0.764) di atas alpha 0.05 .
Tabel 3

Hasil Pengujian Multikolinearitas

\begin{tabular}{|c|l|l|}
\hline \multirow{2}{*}{$\begin{array}{l}\text { Model } \\
\text { (consta } \\
n \text { n) }\end{array}$} & \multicolumn{2}{|c|}{ Colinearuty Statistic } \\
\cline { 2 - 3 } & Toleranc & VIF \\
\hline Kepemilikan manajerial & 0,239 & 4,20 \\
\hline Kepemilikan institusional & 0,371 & 3,16 \\
\hline Proporsi dewan komisaris & 0,316 & 3,26 \\
\hline Keberadaan komite audit & 0,816 & 1,05 \\
\hline
\end{tabular}

Tabel 3 di atas menunjukkan hasil uji multikolonieritas dengan VIF berkisar antara 1,052 sampai 4,203. Sedangkan nilai tolerance berkisar antara 0,239 sampai 0,816. Dari hasil pengujian tersebut dapat disimpulkan bahwa semua variabel independen tidak memiliki masalah multikolinieritas karena nilai $\mathrm{VIF} \leq 10$ dan nilai tolerance $\geq 0.1$. Scatterplot

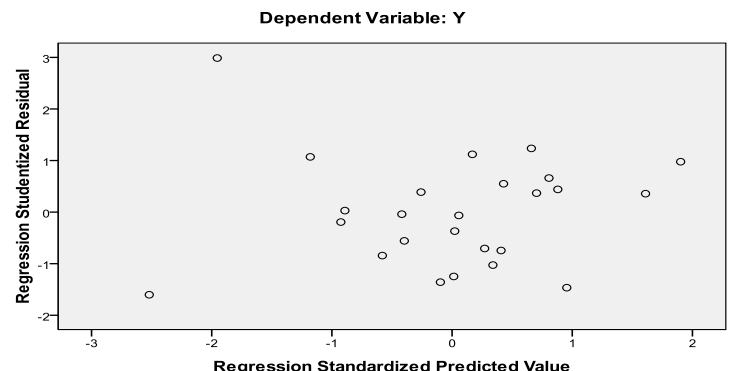

Gambar 1

Scatterplot Grafik

Berdasarkan penggambaran scatterplot di atas, didapatkan bahwa tidak terbentuknya pola yang tersusun rapi. Hal ini dapat diartikan tidak terdapat heteroskedastisitas atau error, sehingga dapat dilakukan pengujian untuk uji selanjutnya.

Hasil uji autokorelasi terhadap model regresi, dapat dilihat pada tabel 4 di bawah ini.

Tabel 4 Hasil Uji Autokorelasi

\begin{tabular}{|l|l|l|}
\hline Model & $\mathrm{R}$ & Durbin-Watson \\
\hline 1 &, 279 (a) & 2,026 \\
\hline
\end{tabular}

a Predictors: (Constant), MNG, INS, DKI, KMT

b Dependent Variable: BTG

Nilai Durbin Watson pada tabel 4 di atas 2,032 ada diantara $\mathrm{Du}=1,746$ sampai $4-\mathrm{Du}=2,254$, yang menunjukkan bahwa model tidak terdapat autokolerasi positif atau negatif. 
Tabel 5

Hasil Uji Statistik F

ANOVA $^{\mathbf{b}}$
\begin{tabular}{|l|l|l|l|l|l|}
\hline Model & $\begin{array}{l}\text { Sum of } \\
\text { Squares }\end{array}$ & df & $\begin{array}{l}\text { Mean } \\
\text { Square }\end{array}$ & F & Sig. \\
\hline $\begin{array}{l}\text { 1 Regressio } \\
\mathrm{n} \\
\text { Residual }\end{array}$ & $\begin{array}{l}1208,71 \\
487,126\end{array}$ & 4 & 604,35 & 819,23 &, 000 \\
& 66 &, 738 & 6 & $\mathrm{a}$ \\
Total & 1696,64 & 66 & & & \\
& 3 & 3 & & & \\
\hline
\end{tabular}

a. Predictors: (Constant), MNG, INS, DKI, KMT

b. Dependent Variable: BTG

Hasil uji statistik F dengan nilai signifikansi sebesar 0,000 menunjukkan bahwa variabel independen dalam model regresi dapat digunakan secara bersama- sama untuk memprediksi book tax gap.

Tabel 6

Hasil Uji Statistik T Coefficients $^{\mathbf{a}}$

\begin{tabular}{|c|c|c|c|c|c|}
\hline \multirow[t]{2}{*}{ Model } & \multicolumn{2}{|c|}{$\begin{array}{l}\text { Unstandardiz } \\
\text { ed } \\
\text { Coefficients }\end{array}$} & \multirow{2}{*}{$\begin{array}{l}\text { Standardiz } \\
\text { ed } \\
\text { Coefficien } \\
\text { ts } \\
\text { Beta }\end{array}$} & \multirow[b]{2}{*}{$\mathrm{t}$} & \multirow[b]{2}{*}{ Sig } \\
\hline & B & $\begin{array}{l}\text { Std. } \\
\text { Error }\end{array}$ & & & \\
\hline $\begin{array}{l}1 \text { (Consta } \\
\text { nt) }\end{array}$ & 1,726 &, 189 & & 9,143 & $\begin{array}{l}, 00 \\
1\end{array}$ \\
\hline MNG &, 169 &, 016 & ,156 & 1,304 & $\begin{array}{l}, 00 \\
1\end{array}$ \\
\hline INS & ,458 &, 011 & ,789 & 2,101 & $\begin{array}{l}, 00 \\
0\end{array}$ \\
\hline DKI &,- 342 &, 029 &,- 420 & $\begin{array}{l}- \\
11,98 \\
3\end{array}$ & $\begin{array}{l}, 17 \\
1\end{array}$ \\
\hline KMT &, 550 &, 041 & ,469 & $\begin{array}{l}13,36 \\
5\end{array}$ & $\begin{array}{l}, 00 \\
0\end{array}$ \\
\hline
\end{tabular}

a. Dependent Variable: BTG

Hasil pengolahan data yang ditunjukkan pada tabel 6, diperoleh model regresi sebagai berikut:

$\mathrm{BTG}=1,726+0,169 \mathrm{MNG}+0,458 \mathrm{INS}-0,342 \mathrm{DKI}$ $+0,550 \mathrm{KMT}+\varepsilon$

\section{Pengaruh Kepemilikan Manajerial Terhadap Tax Management}

Hasil yang diperoleh dari regresi menunjukkan bahwa t hitung dengan nilai 1,304 dan probabilitas signifikansi $0,001<0,05$ maka dapat disimpulkan bahwa kepemilikan manajerial berpengaruh positif terhadap tax management. Hal ini berarti besarnya saham yang dimiliki oleh manajerial akan mempengaruhi aktivitas tax management yang dilakukan oleh perusahaan. Hasil penelitian ini didukung oleh penelitian sebelumnya yang dilakukan oleh Hendra Putra Irawan dan Aria Farahmita (2012) yang menemukan bahwa kepemilikan direksi berpengaruh terhadap manajemen pajak perusahaan. Lebih lanjut dipaparkan bahwa "adanya kepemilikan saham direksi mendorong para eksekutif untuk lebih meningkatkan kinerja perusahaan. Salah satunya dengan manajemen pajak yang baik melalui pengurangan pembayaran pajak perusahaan. Karena dengan usaha tersebut, eksekutif tidak hanya menjalankan keinginan para pemegang saham tetapi juga memberi manfaat atas kepentingan mereka sendiri melalui bottom-line performance yang baik".

\section{Pengaruh Kepemilikan Institusional Terhadap Tax Management}

Hasil yang diperoleh dari regresi menunjukkan bahwa $\mathrm{t}$ hitung dengan nilai 2,101 dan probabilitas signifikansi $0,001<0,05$ maka dapat disimpulkan bahwa kepemilikan institusional berpengaruh positif terhadap tax management. Hal ini berarti kepemilikan institusional yang merupakan proporsi kepemilikan saham oleh institusi di luar perusahaan juga terlibat dalam pengawasan dan pengelolaan perusahaan walaupun kegiatan tersebut dibebankan kepada dewan komisaris atau komisaris independen. Hasil penelitian ini konsisten dengan penelitian yang dilakukan oleh Ngadiman dan Puspitasari (2014) yang mengatakan bahwa kepemilikan institusional memiliki pengaruh signifikan dengan arah positif terhadap tax avoidance.

\section{Pengaruh Proporsi Dewan Komisaris Independen Terhadap Tax Management}

Hasil yang diperoleh dari regresi menunjukkan bahwa $\mathrm{t}$ hitung dengan nilai $-11,983$ dan probabilitas signifikansi $0,171>0,05$ maka dapat disimpulkan bahwa proporsi dewan komisaris independen tidak berpengaruh terhadap tax management. Hasil penelitian ini sejalan dengan penelitian yang dilakukan oleh Maria Meilinda dan Nur Cahyonowati (2013) yang menyebutkan bahwa komisaris independen tidak berpengaruh terhadap tarif pajak efektif yang berarti proporsi dewan komisaris independen tidak berpengaruh terhadap pengelolaan pajak perusahaan. Lebih lanjut dipaparkan bahwa anggota dewan komisaris independen masih belum memenuhi ketentuan peraturan yang ditetapkan pemerintah yaitu $30 \%$ dari dewan komisaris merupakan komisaris independen yang tidak memiliki hubungan dengan internal perusahaan. Sementara pemegang saham mayoritas (pengendali) masih memegang peranan penting sehingga kinerja dewan tidak meningkat bahkan dapat menurun. Penelitian yang dilakukan oleh Batara dan Maria (2015) juga menyatakan bahwa proporsi dewan komisaris independen tidak berpengaruh pada praktik penghindaran pajak. Menurut penelitiannya terdapat beberapa hal yang diduga menjadi alasan mengapa proporsi dewan komisaris independen tidak 
berpengaruh signifikan terhadap tax avoidance. Diantaranya adalah tidak semua anggota dewan komisaris independen dapat menunjukkan independensinya sehingga fungsi pengawasan tidak berjalan dengan baik dan berdampak pada kurangnya pengawasan terhadap manajemen dalam melakukan tax avoidance. Sedangkan hasil penelitian ini tidak sejalan dengan penelitian yang dilakukan oleh Novriansyah Zulkarnaen (2015). Menurut penelitiannya sebetulnya dengan adanya peningkatan atas proporsi komisaris independen akan berakibat pada keefektifan kinerja perusahaan, dalam hal ini termasuk penetapan kebijakan yang berkaitan dengan tarif pajak efektif.

Di Indonesia, keberadaan komisaris independen muncul dikarenakan adanya kenyataan bahwa jabatan komisaris terkadang diberikan bukan didasarkan pada kompetensi dan profesionalisme yang dimiliki, melainkan sebagai penghormatan atau penghargaan yang biasanya diberikan kepada pejabat atau mantan pejabat pemerintah yang masih berpengaruh. Salah satu peran penting komisaris independen yang dapat memberi nilai tambah bagi komisaris secara keseluruhan adalah kecakapannya dalam kepemimpinan baik dalam arti memberi pengaruh secara positif maupun dalam memimpin komitekomite dewan komisaris lainnya (Antonius Alijoyo, \& Subarto Zaini, 2004). Di samping itu, di dapati adanya kecenderungan bahwa komisaris seringkali melakukan intervensi kepada direksi dalam menjalankan tugasnya. Di pihak lain biasanya kedudukan direksi terlalu kuat, bahkan terdapat beberapa direksi perusahaan publik yang enggan membagi wewenang, serta tidak memberikan informasi yang cukup kepada komisaris, terutama komisaris independen (M.Arif Effendi, 2008).

\section{Pengaruh Keberadaan Komite Audit Terhadap Tax Management}

Hasil yang diperoleh dari regresi menunjukkan bahwa $\mathrm{t}$ hitung dengan nilai 13,365 dan probabilitas signifikansi $0,00<0,05$ maka dapat disimpulkan bahwa keberadaan komite audit berpengaruh positif terhadap tax management. Keberadaan komite audit berfungsi untuk menjaga dan meningkatkan kualitas pelaporan keuangan. Hal ini berarti bahwa apabila jumlah komite audit dalam suatu perusahaan tidak sesuai dengan peraturan yang telah ditetapkan oleh OJK maka akan meningkatkan tindakan manajemen dalam melakukan minimalisasi laba untuk kepentingan pajak.

Hasil penelitian ini, diperkuat pula oleh penelitian yang dilakukan oleh Ni Nyoman Kristiana Dewi dan I Ketut Jati (2014). Hasil penelitian yang dilakukan oleh Nuralifnida Ayu Annisa dan Lulus Kurniasih (2012) menemukan bahwa keberadaan komite audit memiliki pengaruh terhadap tax avoidance. Semakin besar jumlah komite audit dalam perusahaan akan meningkatkan kualitas GCG sehingga akan memperkecil kemungkinan aktivitas tax avoidance.

\section{Simpulan dan Saran}

Tujuan dari penelitian ini adalah untuk menguji pengaruh GCG yang diukur melalui mekanisme GCG terhadap tax management pada perusahaan perbankan yang terdaftar di BEI pada periode 2013-2015. Berdasarkan hasil penelitian dan pembahasan maka diperoleh kesimpulan bahwa:

1) Kepemilikan manajerial berpengaruh positif terhadap tax management .

2) Kepemilikan institusional berpengaruh positif terhadap tax management.

3) Proporsi dewan komisaris independen tidak berpengaruh terhadap tax management.

4) Keberadaan komite audit berpengaruh positif terhadap tax management

\section{Keterbatasan Penelitian}

Penelitian ini hanya berfokus pada perusahaan perbankan sehingga hasil penelitian ini juga hanya berlaku pada perusahaan yang menjadi sampel penelitian. Pengukuran GCG pada penelitian ini hanya didasari dari mekanisme GCG (kepemilikan institusional, kepemilikan manajerial, proporsi dewan komisaris independen dan keberadaan komite audit) sehingga pengukuran ini belum dapat menggambarkan penerapan GCG secara menyeluruh. Penelitian berikutnya perlu mempertimbangkan dan mengkomparasikan hasil penelitian pada berbagai jenis perusahaan di luar perbankan. Pengukuran untuk tax management juga dapat menggunakan alat ukur lainnya selain book tax gap, seperti cash ETR seperti yang dilakukan oleh beberapa peneliti sebelumnya.

\section{Daftar Pustaka}

Antonius Alijoyo, \& Subarto Zaini. (2004). Komisaris Independen: Penggerak Praktik GCG di perusahaan. Jakarta : PT. Indeks

ASEAN Corporate Governance Scorecard Country Reports and Assessments. (2014)

Batara Wiryo Pramudita dan Maria M.Ratna Sari. (2015). Pengaruh Konservatisme Akuntansi, Kepemilikan Manajerial dan Ukuran Dewan Komisaris Terhadap Tax Avoidance. E-Journal Akuntansi Universitas Udayana. Vol.13 (3): 705-72.2

Bovi, M. (2005). Book-Tax Gap: An Income Horse Race. ISAE Working Paper. No. 61.

Chen, S., X. Chen, Q. Chen, dan T. Shevlin. (2008). Are family firms more tax aggressive than 
non-family firms? Working Paper. Foster School of Business, University of Washington.

Corporate Governance. Jilid II; Peranan Dewan Komisaris dan Komite Audit dalam Pelaksanaan Corporate Governance.

Desai, M.A dan Dharmapala, D. (2009). Corporate Tax Avoidance and Firm Value. The Review of Economics and Statistics. Vol. 91(3): 537-546.

Fadhilah, Rahmi. (2014). Pengaruh Good Corporate Governance Terhadap Tax Avoidance (Studi Empiris pada Perusahaan Manufaktur yang Terdaftar di Bursa Efek Indonesia 20092011). Jurnal Akuntansi Universitas Negeri Padang. 2 (1).

Firman, A. M. (2013). Kualitas laba, Tax management dan Corporate Governance. Paper Dipresentasikan pada Simposium Nasional Akuntansi XVI, Manado.

Friese, A., Link, S., dan Mayer, S.(2006). Taxation and Corporate Governance. Working paper.

FCGI. Forum for Corporate Governance in Indonesia, Seri Tata Kelola Perusahaan

Imam Ghozali. (2013). Aplikasi Analisis Multivariate dengan Program IBM SPSS 21. Semarang: Universitas Diponogoro

Hendra Putra Irawan dan Aria Farahmita. (2012). Pengaruh Kompensasi Manajemen dan Corporate Governance Terhadap Manajemen Pajak Perusahaan. Paper Dipresentasikan pada Simposium Nasional Akuntansi XV, Banjarmasin

Khirun Nikmah. (2016). Panama Papers Bukti Indonesia Darurat Mafia Perpajakan.

Lal, B.B., dan Vashisht, N. (2008). Direct Taxes. India: Dorling Kindersley.

Maria Meilinda dan Nur Cahyonowati. (2013). Pengaruh Corporate Governance terhadap Manajemen Pajak. Diponegoro Journal of Accounting. Vol 2 (3): 1-13.

M. Arief Effendy. 2016. The Power Of Good Corporate Governance: Teori \& Implementasi. Jakarta: Salemba Empat

M. Arief Effendy (2008). Komisaris Independen Bukan Sekadar Pelengkap. Harian Bisnis Indonesia

McGee. (2008). Corporate Governance In Asia: a Comparative Study. Working Paper. Florida International University

Minnick, K dan Noga, T (2010). Do Corporate Governance Characteristics Influence Tax Management? Journal of Corporate Finance. Vol 16: 703-718.

Ngadiman dan Christiany Puspitasari (2014). Pengaruh Leverage, Kepemilikan Institusional, dan Ukuran Perusahaan terhadap Penghindaran Pajak (Tax
Avoidance). Jurnal Akuntansi. Volume XVIII (03): 408-421.

Ni Nyoman Kristiana Dewi dan I Ketut Jati (2014). Pengaruh karakter eksekutif, karakteristik perusahaan, dan dimensi tata kelola perusahaan yang baik pada tax avoidance di bursa efek Indonesia. E-Jurnal Akuntansi Universitas Udayana. Vol 6(2): 249-260

Nuralifnida Ayu Annisa dan Lulus Kurniasih. (2012). Pengaruh Corporate Governance Terhadap Tax Avoidance. Jurnal Akuntansi dan Auditing. Vol. 8 (2): 95-189.

Novriansyah Zulkarnaen.(2015). Pengaruh Good Corporate Governance Terhadap Manajemen Pajak (Studi Empiris Pada Perusahaan Non-Keuangan Yang Terdaftar di Bursa Efek Indonesia Tahun 2010-2013). Jurnal Bisnis dan Manajemen. Vol. 5(1): 105-118

Sutojo, Siswanto \& E. John Aldridge. (2005). Good Corporate Governance Tata Kelola Perusahaan yang Sehat. Jakarta: PT. Damar Mulia Pustaka.

Utami Indah Dewi \& Rahmawati. (2009). Pengaruh Ukuran Perusahaan, Ukuran Dewan Komisaris, Kepemilikan Institusional, Kepemilikan Asing, dan umur Perusahaan terhadap Corporate Social Responsibility Disclousure pada Perusahaan Property dan Real Estate yang Terdaftar di Bursa Efek Indonesia. Jurnal Akuntansi. Universitas Sebelas Maret Surakarta.

\section{Sumber Internet:}

http://market.bisnis.com/read/20140429$\% 20 / 7 / 223481 /$ gcg-asia-tenggaramenyedihkan-peringkat-ri-nomor-dua-daribawah. 